\title{
Salmonella spp. in non-edible animal products intended for the preparation of feed
} (meal) for industrial poultry feed

\author{
Salmonella spp. em produtos de origem animal não comestíveis destinados a elaboração de ração \\ para alimentação de aves industriais
}

Salmonella spp. en productos animales no comestibles destinados a la producción de piensos para aves industriales

\author{
Wellington Luis Reis Costa \\ ORCID: https://orcid.org/0000-0001-6880-947X \\ Universidade Federal Fluminense, Brazil \\ E-mail: wreiscosta@gmail.com \\ Emília Turlande Sêneca Ribeiro dos Santos \\ ORCID: https://orcid.org/0000-0002-1733-3181 \\ Universidade Federal da Bahia, Brazil \\ E-mail: m.seneca@hotmail.com \\ Antenor Ferreira Leal Neto \\ ORCID: https://orcid.org/0000-0001-7569-5810 \\ Universidade Federal da Bahia, Brazil \\ E-mail: antenor.neto.vet@hotmail.com \\ Rebeca Ayala Rosa da Silva \\ ORCID: https://orcid.org/0000-0002-3687-3570 \\ Universidade Federal da Bahia, Brazil \\ E-mail: rarsilva89@gmail.com \\ Moara de Santana Martins Rodgers \\ ORCID: https://orcid.org/0000-0002-1738-929X \\ Louisiana State University, USA \\ E-mail: moaramartins@hotmail.com \\ Lia Muniz Barretto Fernandes \\ ORCID: https://orcid.org/0000-0003-2723-1952 \\ Universidade Federal da Bahia, Brazil \\ E-mail: liareis@ @erra.com.br \\ Elmiro Rosendo do Nascimento \\ ORCID: https://orcid.org/0000-0003-2316-8933 \\ Universidade Federal Fluminense, Brazil \\ E-mail: elmirorosendo@id.uff.br
}

\begin{abstract}
Non-edible by-products of animal origin are slaughter waste from slaughter animals that after processing give rise to animal meal which in turn is used as ingredients in the preparation of animal feed such as farm animals. Although this practice has its advantages in reducing environmental impact and meeting the nutritional needs of animals, it can serve as a vehicle for microorganisms such as Salmonella spp. Since food can play an important role in the dissemination of pathogens in the poultry production chain through feeding, the objective of the present study was to investigate the presence of Salmonella spp. samples of non-edible flours of animal origin used in the formulation of feed and also of feed produced from these by-products in slaughterhouses received from Bahia and Pernambuco states, Brazil and that are used in the industrial poultry farms of these States. Out of 649 samples of animal origin flours and feed were analyzed, of which 110 (16.9\%) presented Salmonella spp. Statistical analysis, through descriptive analysis and Pearson's chi-squase association test (X2) showed an association between the presence of Salmonella spp. and the different types of inedible foods analyzed $(\mathrm{p}<0.05)$. This contamination in the analyzed samples indicates failure in the microbiological control during and/or after processing of animal origin flours, making them the sources of pathogen dissemination in the poultry chain.
\end{abstract}

Keywords: Salmonelosis; One health; Food safety; Food technology; Non-edible by-products.

\section{Resumo}

Os subprodutos de origem animal não comestíveis são resíduos do abate de animais de açougue que após o processamento dão origem a farinhas de origem animal que por sua vez são utilizadas como ingredientes na 
elaboração de alimentação de animais como os animais de produção. Embora essa prática tenha suas vantagens por reduzir impacto ambiental e suprir necessidades nutricionais dos animais, podem servir de veículo de microrganismos como Salmonella spp. Uma vez que a alimentação pode desempenhar importante papel na disseminação de patógenos na cadeia produtiva de aves através da alimentação, o objetivo do presente estudo foi investigar a presença de Salmonella spp. em amostras de farinhas de origem animal não comestíveis utilizadas na formulação de rações e também de rações produzidas a partir destes subprodutos em abatedouros frigoríficos localizados na Bahia e Pernambuco e que são usadas na avicultura industrial desses Estados. Foram analisadas 649 amostras de farinhas de origem animal e rações, das quais, $110(16,9 \%)$ apresentaram presença de Salmonella spp. A análise estatística, através da análise descritiva e testes de associação qui-quadrado de Pearson $\left(\mathrm{X}^{2}\right)$ mostrou associação entre a presença de Salmonella spp. e os diferentes tipos de alimentos não comestíveis analisados $(p<0,05)$. Essa contaminação nas amostras analisadas revela falhas de controle microbiológico durante e/ou após processamento das farinhas de origem animal, tornando-as potenciais fontes de disseminação do patógeno na cadeia avícola.

Palavras-chave: Salmonelose; Saúde única; Inocuidade dos alimentos; Tecnologia dos alimentos; Alimentos de origem animal não comestíveis.

\begin{abstract}
Resumen
Los subproductos animales no comestibles son residuos del sacrificio de animales de carnicería que, tras su procesamiento, dan lugar a harinas de origen animal, que a su vez se utilizan como ingredientes en la preparación de alimentos para animales como los animales de granja. Si bien esta práctica tiene sus ventajas para reducir el impacto ambiental y cubrir las necesidades nutricionales de los animales, puede servir como vehículo de microorganismos como Salmonella spp. Dado que los alimentos pueden desempeñar un papel importante en la diseminación de patógenos en la cadena de producción avícola a través de los alimentos, el objetivo del presente estudio fue investigar la presencia de Salmonella spp. en muestras de harinas animales no comestibles utilizadas en la formulación de raciones y también de raciones producidas a partir de estos subproductos en mataderos ubicados en Bahía y Pernambuco y que se utilizan en la avicultura industrial de estos Estados. Se analizaron un total de 649 muestras de harinas y piensos animales, de las cuales 110 (16,9\%) presentaron presencia de Salmonella spp. El análisis estadístico, a través del análisis descriptivo y las pruebas de asociación chi-cuadrado de Pearson (X2), mostró una asociación entre la presencia de Salmonella spp. y los diferentes tipos de alimentos no comestibles analizados $(\mathrm{p}<0,05)$. Esta contaminación en las muestras analizadas revela fallas en el control microbiológico durante y/o después del procesamiento de las harinas de origen animal, convirtiéndolas en fuentes potenciales de diseminación de patógenos en la cadena avícola.
\end{abstract}

Palabras clave: Salmonelosis; Salud única; Seguridad alimentaria; Tecnología de alimentos; Alimentos no comestibles de origen animal.

\title{
1. Introduction
}

In the slaughter industry, production residues and other products not suitable for human consumptions, including those arising from condemnation; or obtained inseparably from the slaughter process, including hooves, horns, hair, skin, feathers, beaks, blood, fetal blood, bones, cartilage, intestine mucosa, bile, gallstones, glands, animal waste and any other animal parts are known as non-edible animal products (Brasil, 2020). One way of taking advantage of the residues generated in the slaughter of animals is the production of animal meal (Thyagarajan et al., 2013). The process takes place in the rendering sector and basically consists of grinding and heat treatement of the residues (Malav et al., 2018) using binomials ranging from 115 to $145^{\circ} \mathrm{C}$ for 40 to 90 minutes (Meeker, 2009). Even with the use of high temperatures in the treatment of animal meal, above the thermoresistance of many microbiological contaminants, the animal meal can still present viable microorganisms, including Salmonella spp. (Liu et al., 2018b). For this reason, for microbiological control purposes, the Brazilian legislation recommends periodic analyzes of this pathogen in order to guarantee its absence in 25g of finished product (Brasil, 2008). Commonly, Brazilian companies of integration, use animal meal in diets for non-ruminants, poultry (Ebling et al., 2013) and dogs as a source of protein (Loureiro et al., 2017). Salmonella spp. is considered one of the most important foodborne diseasecausing pathogens worldwide (Abebe et al., 2020). Currently there are 2659 serovars of the genus Salmonella, most of them belonging to the subspecies S. enterica (Issenhuth-Jeanjean et al., 2014). The majority of the serovars that belongs to the enteric subspecies infect humans and warm-blooded animals (Gal-Mor et al., 2014) and are associated with more than 99\% of infections in humans, including gastroenteritis and enteric fevers (Chen et al., 2013). In addition, Salmonella enterica is a 
leading cause of infections in communities of several low and middle-income countries (Deen et al., 2012). According to the presented pathology, Salmonella infections can be divided into enteric fevers, characterized by serious systemic involvement and caused by typhoid Salmonella strains, mainly S. Typhi (typhoid fever) and S. Paratyphi A, B and C (paratyphoid fever); and foodborne infections, characterized most often by the development of self-limited diarrhea caused by a large number of non-typhoid salmonellae (Kagirita et al., 2017; Wain et al., 2015). Particularly, the severity of the infection and whether it will remain localized in the intestines or spread to other organs will depend on the serovar and virulence of Salmonella spp. and/or the host's immune status (De Jong et al., 2012). Almost all strains of Salmonella spp. are pathogenic to man to some degree (Eng et al., 2015), although only approximately 50 of the 2659 existing strains are regularly isolated from humans (Harvey et al., 2017). There are several factors that contribute to the emergence or increase of pathogenicity, among which are: increase in the human population, the existence of vulnerable or more exposed population groups, a disorderly urbanization process and the need for food production in large industrial scales (Ahmed et al., 2019). Food and water contaminated by Salmonella spp. constitute the primary source of human infection by this pathogen (Liu et al., 2018a). Among food that can carry Salmonella spp. those of animal origin, such as meat, milk and eggs are the most frequently observed, especially when they are consumed raw or thermally underprocessed (De Freitas Neto et al., 2010). Other vehicles include contaminated food of plant origin (Fornefeld et al., 2017), through irrigation with water contaminated by fecal material (Garcia et al., 2015). Another important routes of transmission have also been reported, such as contact with surfaces contaminated with organic matter, or with moist soils, water where the agent can survive for long periods (Shah et al., 2019), illicit or occasionally prescribed drugs or fluids and transplacental transmission (Touchan et al., 2009). Infection through direct contact with host/reservoir animals, such as pet birds, mainly in veterinarians and caretakers (Hoelzer et al., 2011), direct contact with reptiles (Friedman et al., 1998) and other animals (De Freitas Neto et al., 2010; Vasconcelos et al., 2018) have also been described. Nosocomial transmission and direct contact with infected people are less important means of infection (Hohmann, 2001). Undercooked eggs, due to transovarian transmission from laying birds or contamination through cracks in the shells, are important routes. However, there was a decrease in infections by Salmonella Enteritidis (Hohmann, 2001; Osowski et al., 2019). Due to this wide distribution of Salmonella spp. in the environment, poultry or the final product can become infected/contaminated from various sources, whether through replacement pullet, hatchery, breeding environment, slaughterhouse, people, failures in biosecurity, management, facilities or through the food. Contamination can occur at any stage of the production chain, from industrial production through transportation and/or storage on the farm until it reaches the final consumer (Finn et al., 2013; Ha et al., 2018; Hoelzer et al., 2011). Regarding the dissemination through contaminated by-products, it was ratified by Li et al. (2021) that various raw materials of animal origin used in the formulation of feeds can lead to the dissemination of Salmonella spp., including S. Enteritidis, for broilers. Leiva et al. (2018) added that meat meal, one of the most used by-products in the manufacture of animal feed, is also one of the highest levels of contamination by Salmonella spp., favoring the spread of the infectious agent. According to Jones (2011), referring especially to Salmonella contamination, processing temperatures eliminate most or even all bacterial contamination, however, the possibility of recontamination of these by-products after leaving the rendering equipment is high due to handling, transportation and other environmental factors. Since recontamination in food processing environments that have already undergone some treatment to reduce pathogenic microorganisms is not usually estimated, sometimes preventive measures are not adopted for this end (Reij et al., 2004). Thus, the objective of this work was to investigate the presence of Salmonella spp. in samples of non-edible animal products intended for the preparation of feed and feed samples made from these residues that are used in poultry feed. 


\section{Methodology}

Study design and sampling: This is a cross-sectional exploratory and observational study. From June 2017 to October 2019, a total of 649 flour samples made from non-edible animal products and rations used in animal feed from 14 slaughterhouses located in the states of Bahia and Pernambuco were analyzed. The samples were processed at the Laboratory of Poultry Health of Bahia, located at the School of Veterinary Medicine, Federal University of Bahia.

Isolation and identification of Salmonella spp.: To determine the presence of Salmonella spp., the classic method was used, as described in the manual of microbiological analysis accepted by the official inspection institutions that regulate the inspection and quality control of non-edible animal products and animal health in Brazil, based on Normative Instructions (IN) No. 34 of May 28, 2008 of the Ministry of Agriculture, Livestock and Supply - MAPA (Brasil, 2008) and Compendium of Methods for the Microbiological Examination of Foods of American Public Health Association (Cox et al., 2015). The method followed the international standard for the presence or absence of Salmonella spp. in $25 \mathrm{~g}$ of analyzed sample. For detection of Salmonella spp. following the steps of pre-enrichment in non-selective broth, enrichment in selective broth, differential selective plating, screening and biochemical tests (Cox et al., 2015), 25g of each sample were aseptically weighed on a precision balance. Subsequently, $225 \mathrm{~mL}$ of 1\% Buffered Peptone Water (BPW) was added to homogenize the samples which were then incubated in a Biochemical Oxygen Demand (BOD) at $37^{\circ} \mathrm{C}$ for 24 hours. After this incubation period, $0.1 \mathrm{~mL}$ aliquots of each sample was taken into $10 \mathrm{~mL}$ of Rappaport-Vassiliaidis Broth (RV) and subsequently incubated in a water bath at $41^{\circ} \mathrm{C}(+2)$, and $1.0 \mathrm{~mL}$ aliquots of each sample to $10 \mathrm{~mL}$ of Tetrathionate Broth (TT) previously enriched with iodine $(0.2 \mathrm{~mL})$ and bright green $(0.1 \mathrm{~mL})$ solutions and subsequently incubated in B.O.D. at $37^{\circ}(+2)$ for 24 hours. The samples were then transferred with the aid of a platinum loop, by making streaks, to the surface of plates containing Xylose Lysine Deoxycholate Agar (XLD), Hektoen Enteric Agar (HE) and Bright Green Agar (VB), followed by incubation in the BOD at $37^{\circ} \mathrm{C}$ for a period of 18 to 24 hours. After incubation, the selection of characteristic colonies suggestive of Salmonella spp. was performed, using an inoculation needle, for screening through biochemical tests.

Statistical analysis: The data was tabulated and analyzed using Pearson's chi-square association tests $\left(\mathrm{X}^{2}\right)$, considering a confidence level of 0.95 (SPSS 17.0 for Windows).

\section{Results and Discussion}

Out of 649collected samples, a total of 110 (16.9\%) isolates of Salmonella spp. was observed, which characterizes the samples analyzed as unfit for consumption by animals according to IN No. 34, which advocates for hygienic-sanitary and operational procedures of Good Manufacturing Practices. Such procedures must be performed in the entire production flow, from obtaining residues to the distribution of the final product, in order to guarantee animal meal free of microbiological contamination (e.g. absence of Salmonella spp./25g). Thus, they can be considered appropriated for production of animal feed. Although the use of animal feed free of Salmonella spp. does not guarantee the absence of infection in the confined broilers, the good manufacturing practices constitute an important measure in the reduction of infections in these animals and, consequently, transmission to humans through the consumption of their meat (Leiva et al., 2018). From the analyzed data, it was possible to verify that out of nine types of samples analyzed, seven were contaminated by Salmonella spp. (Table 1). The lowest frequency of Salmonella spp. observed was in visceral oil, while the highest frequency was observed in meat and bone meal followed by meat meal. However, the number of analyzed samples of meat and bone meal was very small compared to meat meal. 
Table 1: Salmonella spp. isolation frequency by type of non-edible animal products.

\begin{tabular}{|c|c|}
\hline Product & $\begin{array}{c}\text { Frequency } \\
\mathrm{n}(\%)\end{array}$ \\
\hline Meat Meal & $60(23,9)$ \\
\hline Meat and bone meal & $01(33,3)$ \\
\hline Visceral meal & $20(15)$ \\
\hline Feather meal & $24(17,4)$ \\
\hline Slaughter ration & $02(15,4)$ \\
\hline Fattening ration & $00(0)$ \\
\hline Starter ration & $00(0)$ \\
\hline Pre-starter ration & $01(10)$ \\
\hline Offal oil (visceral oil) & $02(4)$ \\
\hline Total & 110 \\
\hline
\end{tabular}

Source: Authors.

This high frequency of Salmonella spp. in these products may be due to the fact that these microorganisms are primarily located in foods with high moisture content and high protein percentage, and their presence in raw meat products may be the result of extensive cross-contamination in industrial plants (Neitzke et al., 2017). Regarding offal oils the low frequency may be related to the low water activity. In foods such as oils and fats, which are insoluble in water, the water activity is below 0.6 and under these conditions the food can be considered microbiologically stable. However, the survival of contaminants can be variable. Vegetative cells can remain viable for days or months and, in the case of sporulated bacteria, they can remain for years (Cebrián et al., 2017; Ulrich et al., 2018). To compare the different types of foods and the frequency of Salmonella spp., a non-parametric Chi-square test was used. The greatest contamination observed in samples of non-edible products of animal origem were in the meat meal, meat and bone meal, visceral meal and feather meal products and their contamination differences from the other products was statistically siginifcant $\left(X^{2}=p=0.001\right)$. Different environmental sources can contribute to the origin of contamination in the broilers production environment, such as water, insects, presence of reptiles and rodents, wild birds and contaminated feed (Sapkota et al., 2014). Several studies have investigated the thermal resistance of Salmonella spp. at various temperatures for various periods of time (Liu et al., 2018b). In general, Salmonella spp. are not able to survive temperatures above $70^{\circ} \mathrm{C}$, with the exception of $S$. Senftenberg. Usually Salmonella spp. are eliminated at $56^{\circ} \mathrm{C}$ for 10 to 20 minutes, although this thermal tolerance increases when the water activity is low or the amount of fat is higher. Whereas serovars of Salmonella spp. are sensitive to the time and temperature binomial used in the heat treatments of the animal meal manufacturing industries (above $133^{\circ} \mathrm{C}$ for at least 20 minutes), food protection would be easily achieved at temperatures lower than those recommended by legislation (Franke-Whittle \& Insam, 2013). Allied to this, the target microbial lethality depends on several factors, among which the following stand out: the thermal resistance of microorganisms and enzymes that may be present; the concentration of cells, time of existence and phase of growth; the parameters of sterilization; the $\mathrm{pH}$ of the food; the physical state of the food; the density or viscosity of the product; the particle size of the product; and the dimensions of the container (Cebrián et al., 2017). Assuming that the contaminating microbiota of processed flours is drastically reduced due to the relative susceptibility of contaminating microorganisms, it can be considered that the risk of spreading a disease through the consumption of such food is low. However, the risk can increase when there is contamination of the food or their contact with other contaminated surfaces. It was observed that out of the 14 slaughouses participating in the survey, eight (57.14\%) had animal feed contaminated by Salmonella spp. (Table 2). The largest numbers of isolates were from 
industries A with 34 (30.09\%) and H with 37 (33.63\%) contaminated samples, followed by industries B with 14 (12.7\%), C with 11 (10\%), J with 9 (8.18\%), and D and N, both with 2 (1.81\%) contaminated samples.

Table 2: Salmonella spp. contamination frequency in non-edible products of animal origen by investigated slaughouse.

\begin{tabular}{|c|c|c|c|c|c|c|c|c|c|c|}
\hline \multirow[b]{2}{*}{$\begin{array}{c}\text { ManufacturingPla } \\
\text { nts }\end{array}$} & \multicolumn{9}{|c|}{ Product type } & \multirow[b]{2}{*}{ Total } \\
\hline & MM & MBM & VM & FM & SR & FR & StR & PSR & $\begin{array}{c}\text { OO } \\
(\mathrm{VO})\end{array}$ & \\
\hline $\mathbf{A}$ & 1 & 0 & 15 & 18 & 0 & 0 & 0 & 0 & 0 & 34 \\
\hline B & 13 & 1 & 0 & 0 & 0 & 0 & 0 & 0 & 0 & 14 \\
\hline $\mathbf{C}$ & 11 & 0 & 0 & 0 & 0 & 0 & 0 & 0 & 0 & 11 \\
\hline D & 2 & 0 & 0 & 0 & 0 & 0 & 0 & 0 & 0 & 2 \\
\hline $\mathbf{E}$ & 0 & 0 & 0 & 0 & 0 & 0 & 0 & 0 & 0 & $\mathbf{0}$ \\
\hline $\mathbf{F}$ & 0 & 0 & 0 & 0 & 0 & 0 & 0 & 0 & 0 & $\mathbf{0}$ \\
\hline $\mathbf{G}$ & 0 & 0 & 0 & 0 & 0 & 0 & 0 & 0 & 0 & $\mathbf{0}$ \\
\hline $\mathbf{H}$ & 21 & 0 & 5 & 6 & 2 & 0 & 0 & 1 & 2 & 37 \\
\hline I & 1 & 0 & 0 & 0 & 0 & 0 & 0 & 0 & 0 & 1 \\
\hline $\mathbf{J}$ & 9 & 0 & 0 & 0 & 0 & 0 & 0 & 0 & 0 & 9 \\
\hline $\mathbf{K}$ & 0 & 0 & 0 & 0 & 0 & 0 & 0 & 0 & 0 & 0 \\
\hline $\mathbf{L}$ & 0 & 0 & 0 & 0 & 0 & 0 & 0 & 0 & 0 & $\mathbf{0}$ \\
\hline $\mathbf{M}$ & 0 & 0 & 0 & 0 & 0 & 0 & 0 & 0 & 0 & 0 \\
\hline $\mathbf{N}$ & 2 & 0 & 0 & 0 & 0 & 0 & 0 & 0 & 0 & 2 \\
\hline Total & 60 & 1 & 20 & 24 & 2 & $\mathbf{0}$ & 0 & 1 & 2 & 110 \\
\hline
\end{tabular}

MM: meat meal; MBM: meat and bone meal; VM: visceral meal; FM: feather meal; SR: slaughet ration; FR: fattening ration; StR: starter ration; PSR: pre-starter ration; OO: offal oil (visceral oil). Source: Authors.

Post-processing contamination is a factor that may explain the presence of Salmonella spp. in the products made in these industries. Taking into account that after heat treatment these raw materials will be ready for consumption, that is, they will not undergo any further treatment, the hands of handlers can play an important role as a vehicle for pathogenic microorganisms, mainly due to inadequate hygiene habits leading to cross contamination (Ehuwa et al., 2021). The skin on the hands has a differentiated population of microorganisms, which can be classified into resident microbiota and transient microbiota. Previously, it was suggested that this microbiota could be reduced by simply washing hands with water and soap or water and detergent (Edmonds-Wilson et al., 2015). However, resident microorganisms are found in the deeper layers of the skin and are therefore not easily removed by mechanical friction. Most of this microbiota (85\%) is constituted by coagulasenegative staphylococci, such as Staphylococcus epidermidis, and the smallest part (5-25\%) by coagulase-positive staphylococci, such as S. aureus and other microorganisms of the Corynebacterium, Propionibacterium and Acinetobacter genera. The transitory skin microbiota, on the other hand, is represented by the microorganisms that the individual had contact, and which do not multiply on the skin, but remain on it, being able to contaminate other surfaces and foods; among them are enterobacteria such as Escherichia coli and Salmonella spp. and also viruses, fungi and parasites (Byrd et al., 2018). Another factor related to contamination in the production environment is biofilm formation by Salmonella spp. Biofilms are structures that stand out for their ability to form in various types of environments, whether biotic or abiotic (Steenackers et al., 2012). Research on its formation on surfaces of material used in food production environments, such as stainless steel, has been highlighted mainly with regard to its impact on the dangers of its presence (Wang et al., 2016). Once formed, biofilms act as points of constant contamination, releasing cells of pathogenic and/or deteriorating microorganisms, compromising the microbiological quality of the raw material or finished products (Boari et al., 2009). It was possible to verify during this study that there was a decrease in the isolation of Salmonella spp. in the samples sent to the laboratory. Probably the industries involved in the research intensified the Good Manufactures Practices in order to meet the microbiological control of the produced non-edible animal products after the results of the first analyses. Gandolfi \& Ramos (2002) also described a 
reduction in the percentage of positive samples for the microorganism during his research and stated that the decline occurred as corrective and preventive measures were taken after the perception of failures in the processing of by-products. The present study was carried out in two phases, with a $65 \%$ reduction of positivity in the second phase for the incidence of Salmonella spp. in the analyzed animal meal products. Microbiological contamination of food is a global public health problem. In Brazil, the Regulation for Industrial and Sanitary Inspection of Products of Animal Origin (RIISPOA), of the Ministry of Agriculture, Livestock and Supply (MAPA), is responsible for the standards established to ensure the identity and quality of products of animal origins (Brasil 2020). However, the results found in this study show the need for more effective and permanent inspection at all stages of production, including primary production by official inspection services, as an extremely important measure and, therefore, indispensable to the maintenance of population health.

\section{Conclusion}

Contamination by Salmonella spp. in the analyzed samples has revealed failures in the microbiologic control during and/or after the processing of animal meal, making them potential sources of pathogen dissemination. Based on the results obtained, it can be inferred that laboratory monitoring of these by-products is of fundamental importance and the continuity of studies so that prevention and control measures are better understand and animal feeding is no longer a industrial or sanitary risk. Moreover, additional studies must be carried out in order to genotypically identify the Salmonella spp. isolates from the analyzed samples, with the purpose of tracking and identifying the possible source of contamination.

\section{References}

Abebe, E., Gugsa, G., \& Ahmed, M. (2020). Review on major food-borne zoonotic bacterial pathogens. Journal of tropical medicine, 2020. $10.1155 / 2020 / 4674235$.

Ahmed. S., Dávila, J. D., Allen, A., Haklay, M., Tacoli, C., \& Fèvre, E. M. (2019). Does urbanization make emergence of zoonosis more likely? Evidence, myths and gaps. Environment and urbanization, 31(2), 443-460. 10.1177/0956247819866124.

Boari, C. A; Alves, M. P; Tebaldi, V. M. R.; Savian, T. V., \& Piccoli, R. H. (2009). Formação de biofilme em aço inoxidável por Aeromonas hydrophila e Staphylococcus aureus usando leite e diferentes condições de cultivo. Ciência e Tecnologia de Alimentos, 299(4), 886-895.

Brasil (2008) Ministério da Agricultura, Pecuária e Abastecimento. Regulamento Técnico da Inspeção Higiênico Sanitária e Tecnológica do Processamento de Resíduos de Animais e o Modelo de Documento de Transporte de Resíduos Animais. Instrução Normativa $n^{\circ} 34$, de 28 de maio de 2008 . Retrieved december 21, 2018. from http://sistemasweb.agricultura.gov.br/sislegis/action/detalhaAto.do?method=visualizarAtoPortalMapa\&chave=284275208.

Brasil (2020) Ministério da Agricultura, Pecuária e Abastecimento. Secretaria de Defesa Agropecuária. Departamento de Inspeção de Produtos de Origem Animal. Regulamento da Inspeção Industrial e Sanitária de Produtos de Origem Animal. Decreto nº 10.468 , de 18 de agosto de 2020 . Retrieved november 18, 2020. From https://www.in.gov.br/web/dou/-/decreto-n-10.468-de-18-de-agosto-de-2020-272981604.

Byrd, A. L., Belkaid, Y., \& Segre, J. A. (2018). The human skin microbiome. Nature Reviews Microbiology, 16(3), 143-155. 10.1038/nrmicro.2017.157.

Cebrián, G., Condón, S., \& Mañas, P. (2017). Physiology of the inactivation of vegetative bacteria by thermal treatments: mode of action, influence of environmental factors and inactivation kinetics. Foods, 6(12), 107. 10.3390/foods6120107.

Chen, H. M., Wang, Y., Su, L. H., \& Chiu, C. H. (2013). Nontyphoid Salmonella infection: microbiology, clinical features, and antimicrobial therapy. Pediatrics \& Neonatology. 54, 147-152. 10.1016/j.pedneo.2013.01.010.

Cox, N. A., Frye, J. G., McMahon, W., Jackson, C. R., Richardson, J., Cosby, D. E., Mead, G., \& Doyle, M. P. (2015). "Salmonella”, Compendium of Methods for the Microbiological Examination of Foods. Washington: American Public Health Association.

Deen, J., Von Seidlein, L., Andersen, F., Elle, N., White, N. J., \& Lubell, Y. (2012). Community-acquired bacterial bloodstream infections in developing countries in south and southeast Asia: a systematic review. The Lancet infectious diseases. 12, 480-487.

De Freitas Neto, O. C.; Penha Filho, R. A. C., Barrow, P., \& Berchieri Junior, A. (2010). Sources of human non-typhoid salmonellosis: a review. Brazilian Journal of Poultry Science. 12 (1), 01-11.

De Jong, H. K., Parry, C. M., Van, Der Poll, T., \& Wiersinga, W. J. (2012). Host-pathogen interaction in invasive salmonellosis. PLOS Pathogens. 8 (10), e1002933. Retrieved Juy 7, 2021, from https://journals.plos.org/plospathogens/. 
Ebling, P. D., Ribeiro, A.M.L., Trevizan, L., da Silva, I. C. M. \& Kessler, A. D. M. \& Rubin, L. L. (2013). Effect of different dietary concentrations of amino acids on the performance of two different broiler strains. Brazilian Journal of Poultry Science, 15, 339-346.

Edmonds-Wilson, S. L., Nurinova; N. I.; Zapka, C. A., Fierer, N., \& Wilson, M. (2015). Review of human hand microbiome research. Journal of dermatological science, 80(1), 3-12.

Ehuwa, O., Jaiswal, A. K., \& Jaiswal, S. (2021). Salmonella, Food Safety and Food Handling Practices. Foods, 10(5), 907. 10.3390/foods10050907.

Eng, S. K., Pusparajah, P., Ab Mutalib, N. S., Ser, H. L., Chan, K. G., \& Lee, L. H. (2015). Salmonella: a review on pathogenesis, epidemiology and antibiotic resistance. Frontiers in Life Science, 8(3), 284-293. 10.1080/21553769.2015.1051243.

Finn, S., Condell, O., McClure, P., Amézquita, A., \& Fanning, S. (2013). Mechanisms of survival, responses and sources of Salmonella in low-moisture environments. Frontiers in microbiology, 4, 331.doi:10.3389/fmicb.2013.00331.

Fornefeld, E., Schierstaedt, J., Jechalke, S., Grosch, R. Smalla, K., \& Schikora, A. (2017). Interaction between Salmonella and plants: potential hosts and vectors for human infection. Current Topics in Salmonella and Salmonellosis, 171-191. 10.5772/67061.

Franke-Whittle, I. H.\& Insam, H. (2013) Treatment alternatives of slaughterhouse wastes, and their effect on the inactivation of different pathogens: A review. Critical reviews in microbiology. 39 (2), 139-151.

Friedman, C. R., Torigian, C., Shillam, P. J., Hoffman, R. E., Heltze, D., Beebe, J. L., Malcolm, G., DeWitt, W. E. Hutwagner, L., \& Griffin, P. M. (1998). An outbreak of salmonellosis among children attending a reptile exhibit at a zoo. The Journal of pediatrics. 132: 802-807. 10.1016/S0022-3476(98)70307-5.

Gal-Mor, O., Boyle, E. C., \& Grassl, G.A. (2014). Same species, different diseases: how and why typhoidal and non-typhoidal Salmonella enterica serovars differ. Frontiers in microbiology, 5: 391.10.3389/fmicb.2014.00391.

Gandolfi, C. S., \& Ramos, M. I. L. (2002) Salmonella sp. em farinhas de origem animal utilizadas na elaboração de rações para aves. Revista Higiene Alimentar, 16 (102/103), 112-116.

Garcia, B. C. B., Dimasupil, M. A. Z., Vital, P. G., Widmer, K. W., \& Rivera, W. L. (2015). Fecal contamination in irrigation water and microbial quality of vegetable primary production in urban farms of Metro Manila, Philippines. Journal of Environmental Science and Health, Part B, 50(10), 734-743. $10.1080 / 03601234.2015 .1048107$

Ha, J. S., Seo, K. W., Kim, Y. B., Kang, M. S., Song, C. S., \& Lee, Y. J. (2018). Prevalence and characterization of Salmonella in two integrated broiler operations in Korea. Irish veterinary journal, 71(1), 1-9. 10.1186/s13620-018-0114-4.

Harvey, R. R., Friedman, C. R., Crim, S. M., Judd, M., Barrett, K. A., Tolar, B., Folster, J. P., Griffin, P. M., \& Brown, A. C. (2017) Epidemiology of Salmonella enterica serotype Dublin infections among humans, United States, 1968-2013. Emerging infectious diseases, 23(9), 1493. 10.3201/eid2309.170136.

Hoelzer, K., Switt, A. I. M., \& Wiedmann, M. (2011) Animal contact as a source of human non-typhoidal salmonellosis. Veterinary research, 42(1), 1-28. Retrieved October 26, 2021, from http://www.veterinaryresearch.org/content/42/1/34.

Hohmann, E. L. (2001). Nontyphoidal salmonellosis. Clinical Infectious Diseases, 32 (2), 263-269. 10.1086/318457.

Issenhuth-Jeanjean, S., Roggentin, P., Mikoleit, M., Guibourdenche, M., De Pinna, E., Nair, S., \& Weill, F. X. (2014). Supplement 2008-2010 (no. 48) to the White-Kauffmann-Le Minor scheme. Research in microbiology, 165 (7), 526-530. 10.1016/j.resmic.2014.07.004.

Jones, F.T. (2011). A review of practical Salmonella control measures in animal feed. Journal of Applied Poultry Research, 20(1), 102-113. 10.3382/japr.2010-00281.

Kagirita, A. A., Baguma, A., Owalla, T. J., Bazira, J., \& Majalija, S. (2017). Molecular Characterization of Salmonella from Human and Animal Origins in Uganda. International journal of bacteriology. 2017. 10.1155/2017/4604789.

Leiva, A., Granados-Chinchilla, F., Redondo-Solano, M., Arrieta-González, M., Pineda-Salazar, E., \& Molina, A. (2018). Characterization of the animal byproduct meal industry in Costa Rica: Manufacturing practices through the production chain and food safety. Poultry science, $97(6)$, 2159-2169. $10.3382 / \mathrm{ps} / \mathrm{pey} 058$

Li, S., He, Y., Mann, D. A., \& Deng, X. (2021). Global spread of Salmonella Enteritidis via centralized sourcing and international trade of poultry breeding stocks. Nature communications, 12(1), 1-12. 10.1038/s41467-021-25319-7.

Liu, H., Whitehouse, C. A., \& Li, B. (2018a). Presence and persistence of Salmonella in water: the impact on microbial quality of water and food safety. Frontiers in Public Health, 6, 159.

Liu, S., Tang, J., Tadapaneni, R. K., Yang, R., \& Zhu, M. J. (2018b). Exponentially increased thermal resistance of Salmonella spp. and Enterococcus faecium at reduced water activity. Appl. Environ. Microbiol. 84 (8), e02742-17. 10.1128/AEM.02742-17.

Loureiro, K. D. C., Haese, D., Kill, J. L., Pires, A. F., Fernandes, D. R., Colnago, G. L., Lucas, W., \& Gama, G. O. (2017). Ingredients derived from the slaughter of bovines in dog food. Ciência Rural, 47: 06, e20150778.10.1590/0103-8478cr20150778.

Malav, O. P., Birla, R., Virk, K. S., Sandhu, H. S., Mehta, N., Kumar, P., \& Wagh, R.V. (2018). Safe Disposal of Slaughter House Waste. Safe Disposal of Slaughter House Waste. Appro Poult Dairy \& Vet Sci. 2(4). APDV.000542. 10.31031/APDV.2018.02.000542.

Meeker, D. L. (2009). North American Rendering: processing high quality protein and fats for feed. Revista Brasileira de Zootecnia, 38 , SPE, 432-440. 
Research, Society and Development, v. 11, n. 3, e16311326310, 2022

(CC BY 4.0) | ISSN 2525-3409 | DOI: http://dx.doi.org/10.33448/rsd-v11i3.26310

Neitzke, D. C., Roza, C. R., Weber, F. H. (2017). Segurança dos alimentos: contaminação por Salmonella spp. no abate de suínos. Brazilian Journal of Food Technology, 20, e2015063. 10.1590/1981-6723.6315.

Osowski, G. V., Baron, L. F., Coldebella, A., Fonseca, F. N., Mota, S. C. A., Degenhardt, R., Duarte, S. C. (2019). Comparative study of egg contamination with Salmonella Heidelberg and Salmonella Typhimurium. Brazilian Journal of Veterinary Research and Animal Science, 56(1), e150479-e150479. doi 10.11606/issn.1678-4456.bjvras.2019.150479.

Reij, M. W., \& Den Aantrekker, E. D.; ILSI Europe Risk Analysis in Microbiology Task Force (2004). Recontamination as a source of pathogens in processed foods. International Journal of Food Microbiology. 91(1),1-11. 10.1016/S0168-1605(03)00295-2.

Sapkota, A. R., Kinney, E.L., George, A., Hulet, R. M., Cruz-Cano, R., Schwab, K. J., \& Joseph, S. W. (2014). Lower prevalence of antibiotic-resistant Salmonella on large-scale US conventional poultry farms that transitioned to organic practices. Science of the Total Environment, 476, 387-392. 10.1016/j.scitotenv.2013.12.005.

Shah, M. K., Bradshaw, R., Nyarko, E., Handy, E. T., East, C., Millner, P. D., Bergholz, T. M., \& Sharma, M. (2019) Salmonella enterica in soils amended with heat-treated poultry pellets survived longer than bacteria in unamended soils and more readily transferred to and persisted on spinach. Applied and environmental microbiology, 85(10), e00334-19. 10.1128/AEM.00334-19.

Steenackers, H., Hermans, K., Vanderleyden, J., \& De Keersmaecker, S. C. (2012). Salmonella biofilms: an overview on occurrence, structure, regulation and eradication. Food Research International, 45(2), 502-53. 10.1016/j.foodres.2011.01.038.

Thyagarajan, D., Barathi, M., \& Sakthivadivu, R. (2013) Scope of poultry waste utilization. IOSR Journal of Agriculture and Veterinary Sciences. 6(5), 29-35.

Touchan, F., Hall, J. D., \& Lee, R.V. (2009). Typhoid fever during pregnancy: case report and review. Obstetric medicine. 2(4), 161-163. 10.1258/om.2009.090020.

Ulrich, N., Nagler, K., Laue, M., Cockell, C. S., Setlow, P., \& Moeller, R. (2018). Experimental studies addressing the longevity of Bacillus subtilis sporesThe first data from a 500-year experiment. PloS one, 13(12), e0208425. 10.1371/journal.pone.0208425.

Vasconcelos, R. H., Teixeira, R. S. D. C., Silva, I. N. G. D., Lopes, E. D. S., Maciel, W. C. (2018). Feral pigeons (Columba livia) as potential reservoirs of Salmonella sp. and Escherichia coli. Arquivos do Instituto Biológico. 85: 1-6, e0412017. 10.1590/1808-1657000412017.

Wain, J., Hendriksen, R. S., Mikoleit, M. L., Keddy, K. H., Ochiai, R. L. (2015). Typhoid fever. The Lancet. 385,1136-1145. 10.1016/ S0140-6736(13)627087

Wang, H., Wang, H., Xing, T., Wu, N., Xu, X., \& Zhou, G. (2016). Removal of Salmonella biofilm formed under meat processing environment by surfactant in combination with bio-enzyme. LWT-Food Science and Technology, 66, 298-304. 10.1016/j.1wt.2015.10.049. 